\title{
Contributions to the knowledge of Banasa Stål (Hemiptera, Heteroptera, Pentatomidae): Banasa chaca Thomas
}

\author{
Thereza de Almeida Garbelotto ${ }^{1}$, Filipe Michels Bianchi ${ }^{1}$, Luiz Alexandre Campos ${ }^{1} \&$ Jocélia Grazia $^{1,2}$ \\ ${ }^{1}$ Programa de Pós-Graduação em Biologia Animal, Departamento de Zoologia, Universidade Federal do Rio Grande do Sul, Av. Bento Gonçalves \\ 9500, 91501-970 Porto Alegre-RS, Brasil. luiz.campos@ufrgs.br \\ ${ }^{2} \mathrm{CNPq}$ fellow. jocelia@ufrgs.br
}

\begin{abstract}
Contributions to the knowledge of Banasa Stål (Hemiptera, Heteroptera, Pentatomidae): Banasa chaca Thomas. The male of Banasa chaca Thomas is described with emphasis on external and internal genitalia and the female internal genitalia is described. Banasa chaca is newly recorded from Buenos Aires Province (Argentina).
\end{abstract}

KEYWORDS. Ilex paraguariensis; morphology of genitalia; Neotropical Region; Pentatominae; taxonomy.

RESUMO. Contribuições ao conhecimento de Banasa Stål (Hemiptera: Heteroptera: Pentatomidae: Pentatominae): Banasa chaca Thomas. O macho de Banasa chaca Thomas é descrito com ênfase na genitália externa e interna, também é descrita a genitália interna da fêmea. Banasa chaca é registrada pela primeira vez na província de Buenos Aires (Argentina).

PALAVRAS-CHAVE. Ilex paraguariensis; morfologia da genitália; Pentatominae; Região Neotropical; taxonomia.

Banasa Stål is widely distributed in the Americas, ranging from southern Canada to Argentina (Thomas \& Yonke $1981,1988,1990)$. The genus is one of the most diverse among Pentatomidae, with 80 known species, and new taxa are still being described (Campos et al. 2010). Besides the description of new taxa, information about the known species is also necessary, for instance expanding biogeographic boundaries, finding immature stages or undescribed sexes.

Thomas \& Yonke (1985) divided Banasa into 11 species groups mostly based in male characters. One of these groups is the patagiata, the second larger group in number of species (12), which occur in tropical and subtropical areas from Central through South America, except Amazonia (Thomas \& Yonke 1985, 1990).

Banasa chaca Thomas was described for one female from Argentina, and included into the patagiata group due to the blunt and broad abdominal tubercle (Thomas \& Yonke 1990). The species was posteriorly recorded in Brazil (Santa Catarina) by Chiaradia \& Milanez (2007). Here we describe the male of $B$. chaca with emphasis on external and internal genitalia. The internal genitalia of the female is also described.

Adults of B. chaca (3 females, 3 males) were collected by F.M.B. in Araranguá and by L.A.C. (1 male) in Imbituba (Santa Catarina, Brazil, respectively $-29.03910,-49.52619$ and $-28.2333,-48.6667$ ); two males were sent to J.G. for identification, collected in Chapecó (Santa Catarina, Brazil, $-27.1000,-52.6000)$, as well as 2 males and 3 females from Castelar (Buenos Aires, Argentina, -34.6667, -58.6667). The specimens from Chapecó and Castelar were collected on Ilex paraguariensis St. Hill. (Aquifoliaceae). All the specimens studied are deposited in the collection of the Departamento de Zoologia, Universidade Federal do Rio Grande do Sul, Porto Alegre, RS, Brazil (UFRGS). Measurements (minimum and maximum) are given in millimeters. The terminology of Dupuis (1970) is adopted for the structure of the genitalia; dissection and illustration of genitalia follow Grazia et al. (2000).

\section{Banasa chaca Thomas, 1990}

(Figs 1-10)

Distribution. ARGENTINA: Misiones, Buenos Aires (NEW RECORD); BRAZIL: Santa Catarina.

Male (Fig. 1). General color and morphology as described by Thomas \& Yonke (1990) for the female holotype. Measurements $(n=5)$ : head length $(1.50-1.80)$; width (2.10-2.25); length of antennal segments: I (0.43-0.47); II (0.59-0.62); III (0.74-0.86); IV (0.98-1.09); V (1.17-1.21); pronotum length (1.80-2.10); width (4.80-5.40); scutelum length (3.00-3.60); width (3.15-3.60); body length (7.808.40); abdominal width (4.80-5.10).

Genitalia. Pygophore subquadrangular, posterolateral angles truncate. Dorsal rim subrectilinear edged by dense setae (Fig. 2). Ventral rim sinuous, deeply excavated mesally (Fig. 3). Surface of ventral wall shallowly depressed between posterolateral angles, projected dorsad partially covering parameres and proctiger posteriorly (Fig. 4). Lateral margins 


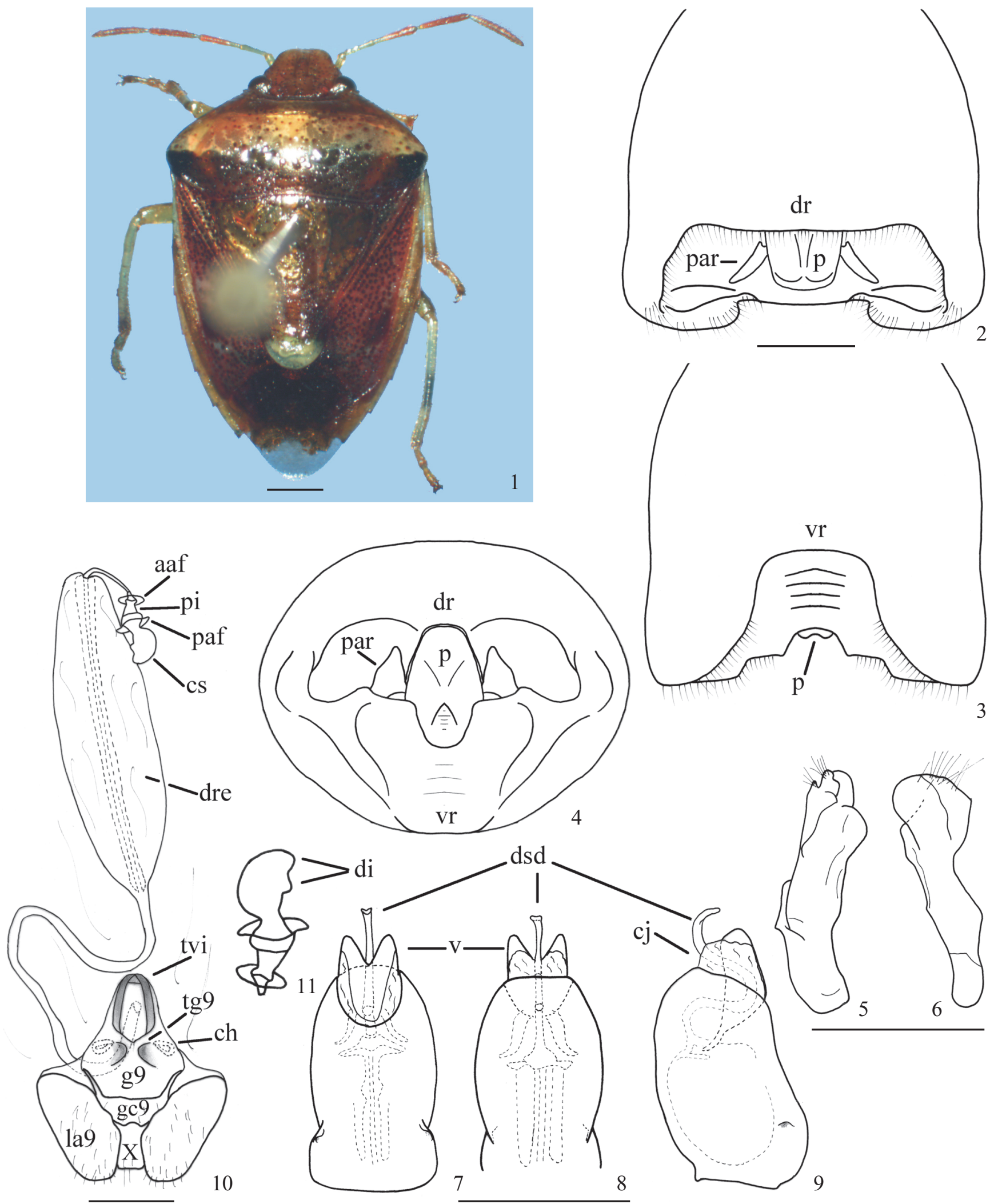

Figs. 1-11. Banasa chaca Thomas, 1-9 male, 10-11 female. 1, dorsal view; 2-4, pygophore, respectively dorsal, ventral, and posterior; 5-6, left paramere, lateral and mesial; 7-9, phallus, respectively dorsal, ventral, and lateral; 10, receptaculum seminis and ausenwand, ventral; 11, capsula seminalis and ductus receptaculis. aaf: anterior annular flange; ch: chitinellipsen; cj: conjunctiva; cs: capsula seminalis; di: diverticula; dr: dorsal rim; dre: ductus receptaculi; dsd: ductus seminis distalis; g9: gonapophyses 9; gc9: gonocoxites 9; la9: laterotergites 9; p: proctiger; paf: posterior annular flange; par: paramere; pi: pars intermedialis; tg9: thickening of gonapophyses 9; tvi: thickening of vaginal intima; v: vesica; vr: ventral rim; X: tenth segment. Scales $: 1=1 \mathrm{~mm} ; 2-9=0.5 \mathrm{~mm}$; figures 5,6 and 11 in the same scale. 
delimiting this depression with dense setae (Fig. 3). Parameres long and curved, apex subtriangular (Figs. 5, 6). Proctiger slightly bilobate at apex (Figs. 2, 3). Phallus simple, robust, longer than wide (Figs. 7-9). Phallotheca bearing 1+1 basal processes. Conjunctiva covering ventro-laterally the base of vesica (Figs. 8, 9). Vesica short, dorsally bilobed (Figs. 7, 8); ductus seminis distalis curved, surpassing apex of vesica (Figs 7-9).

Female. Measurements $(\mathrm{n}=7)$ : head length $(1.50-1.90)$; width (2.10-2.4); length of antennal segments: I (0.40-0.50); II (0.40-0.60); III (0.80-1.10); IV (0.10-1.11); V (1.10-1.30); pronotum length (1.60-2.10); width (4.80-5.70); scutelum length (3.10-3.90); width (3.00-3.50); body length (8.409.80); abdominal width (4.60-5.60).

Internal genitalia (Figs. 10, 11). Gonapophyses 9 with $1+1$ arched sclerotized areas close to elliptical ring sclerites (chitinellipsen, sensu Dupuis 1955). Thickening of the vaginal intima somewhat elliptical. Ductus receptaculi before the vesicular area subequal in length to this area. Pars intermedialis short, constricted at base; anterior and posterior annular flanges directed toward ductus receptaculi. Capsula seminalis constricted at base, anterior lobe subequal in length to pars intermedialis, posterior lobe bearing two diverticula laterally directed; margin of capsula opposite to diverticula convex.

Comments. The inclusion of $B$. chaca into the patagiata group is confirmed by characteristics of male pygophore, namely ventral rim with a deep, narrow, quadrate emargination (Figs. 3, 4, vr), and proctiger bilobate (Figs. 2, 4, p), as well as by the presence of two diverticula at capsula seminalis in the female internal genitalia (Fig. 11, di). Ilex paraguariensis Saint Hilaire (Aquifoliaceae) was first recorded as a host of $B$. chaca by Chiaradia \& Milanez (2007).

Material examined: BRAZIL, Santa Catarina: Chapecó, 2 males, 2 females, 24/III/2004, Chiaradia, L. leg.; Hosp.: erva mate [-27.1000,
-52.6000]; Imbituba, 1 male, 1994, Campos, L. A. leg. [-28.2333, -48.6667]; Araranguá, 1 male, 2009/IV/24, Bianchi, F. M. leg. [-29.03910, -49.52619]; 1 male, 1 female, 2009/IV/30, Bianchi, F. M. leg. [-29.03910, -49.52619]; 1 male, 1 female, 2009/V/18, Bianchi, F. M. leg. [-29.03910, -49.52619]. ARGENTINA, Buenos Aires: Castelar, 2 males, 3 females, 30/III/1995, Saini, E. leg.; s/yerba mate [-34.6667, -58.6667].

\section{REFERENCES}

Campos, L. A.; J. Grazia; T. A. Garbelotto; F. M. Bianchi \& N. C. Lanzarini. 2010. A new South American species of Banasa Stål (Hemiptera: Heteroptera: Pentatomidae: Pentatominae): from egg to adult. Zootaxa 2559: 47-57.

Chiaradia, L. A. \& J. M. Milanez. 2007. Pragas da erva-mate no Estado de Santa Catarina. Florianópolis, Epagri. 38 p. (Boletim Técnico No 134)

Dupuis, C. 1955. Les genitalia des Hémiptères-Hétéroptères (genitalia externes des deux sexes; voies ectodermiques femelles): revue de la morphologie. Mémoires du Muséum National d'Histoire Naturelle, Nouvelle Série [A, Zoologie] 6: 183-278.

Dupuis, C. 1970. Heteroptera, p. 190-208. In: S. L. Tuxen (ed.). Taxonomist's Glossary of Genitalia of Insects. Copenhagen, Munksgaard, $359 \mathrm{p}$.

Grazia, J.; L. A. Campos \& M. Becker. 2000. Revision of Cataulax Spinola, with Architas Distant as a new synonymy (Heteroptera: Pentatomidae: Discocephalini). Anais da Sociedade Entomológica do Brasil 29: 475488

Thomas, D. B. \& T. R. Yonke. 1981. Review of the Nearctic species of the genus Banasa Stål (Hemiptera: Pentatomidae). Annals of the Entomological Society of America 54: 233-248.

Thomas, D. B. \& T. R. Yonke. 1985. Cladistic analysis of zoogeography and polyploid evolution in the stinkbug genus Banasa Stål (Hemiptera: Pentatomidae). Annals of the Entomological Society of America 78: $855-862$.

Thomas, D. B. \& T. R. Yonke. 1988. Review of the genus Banasa Stål 1860 (Hemiptera: Pentatomidae) for Mexico, Central America, and the Antilles. Annals of the Entomological Society of America 81: 2849.

Thomas, D. B. \& T. R. Yonke. 1990. Review of the genus Banasa (Hemiptera: Pentatomidae) in South America. Annals of the Entomological Society of America 83: 657-688. 